\title{
Plants Flowering and Fruiting Behaviour in Alas Purwo National Park, Banyuwangi, East Java
}

\author{
Dewi Ayu Lestari ${ }^{1 *}$, Agung Sri Darmayanti ${ }^{1}$ \\ 1) Purwodadi Botanic Garden, Research Center for Plant Conservation and Botanic Garden, Indonesian Institute of Sciences \\ (LIPI), Jl. Surabaya-Malang Km. 65, Purwodadi, Pasuruan, East Java 67163
}

Submitted: 03 February 2020; Accepted: 27 June 2020; Published: 15 August 2020

\begin{abstract}
Alas Purwo National Park (APNP) is a conservation area with lowland forest type. The adaptation of plants conserved is strongly influenced by environmental factors and the behaviour of flowering and fruiting. The aims of this research were to find the number, species, dominance, and abundance of flowering and fruiting plants, comparison of flowering and fruiting species, and environmental factors affecting the flowering and fruiting time in APNP observation tracks. This study used purposive random sampling in each observation track where flowering and fruiting plants were found. Environmental factors (temperature, humidity, light intensity, soil $\mathrm{pH}$, elevation, and coordinates) in each observation track were measured. Data analysis was conducted using Microsoft Excel and PAST 4.0. statistic program. The behaviour of flowering and fruiting plants species in APNP was unique. There were 90 species of flowering and fruiting plants in APNP from 45 families. Most species often found flowering and fruiting were Orophea enneandra, Polyalthia littoralis and Leea angulata which were scattered in Moto Lele, Patirtan Mas, and Sadengan Savanna. Fruiting plants species were more often found than flowering ones. Temperature and light intensity became the two most affecting environmental factors on flowering and fruiting plants behaviour. The study of flowering and fruiting behaviour is very important for genetic resources conservation and conservation areas management.
\end{abstract}

Keywords: Alas Purwo National Park, behaviour, conservation, flowering, fruiting

\section{INTRODUCTION}

According to the Regulation of the Indonesian Minister of Environment and Forestry No. 46/2016 article 1 paragraph 2, a national park is a natural conservation area with an original ecosystem, managed with a zone system utilized for research, science, education, tourism, recreation and supporting cultivation. Based on this regulation, native plants of each national park area must be maintained since it is the icon of this area. The types of most national parks in eastern Java are lowland forests, including Alas Purwo National Park (APNP). Lowland rainforest becomes the dominant area of APNP with mangrove and coastal forest as additional formations on an altitude of $0-322 \mathrm{~m}$ asl. According to Tisnawati et al. (2012), more than 700

\footnotetext{
*Corresponding author

Tel.: +62 341426046

Email: chunyang_dee@yahoo.co.id

(C) 2020, J. Tropical Biodiversity Biotechnology (CC BY-SA 4.0)
}

plant species were identified from 123 families within this area. Lowland rainforests were dominated by bamboo vegetation, in which the highest numbers of species were within the family of Verbenaceae and Poaceae (Hidayat, 2008). The huge number of rare plants having potential as medicine in APNP causes it to be vulnerable to exploitation (Hidayat, 2008) and the existence of native plants could be threatened.

Information concerning the adaptation of plants to their environment, especially to climate change, is available through the observation of the behaviour of flowering and fruiting since it is one of the biological activities affected by the ecological factors of a plant (Nanda et al., 2017) and microclimate factors (Lestari \& Sofiah, 2015). Changes in plant behaviour factors when flowering and fruiting affect the efforts for its conservation. Each plant has different flowering and fruiting behaviour (phenological characters) because it is 
influenced by genetic and environmental character (Goldsworthy \& Fisher, 1992; Milla et al., 2006). Plants flowering and fruiting behaviour comprises the pattern and period of flowering and fruiting. It greatly affects the conservation efforts of these species in nature since the information of the pattern and period of flowering and fruiting leads to be understanding of plants response to their environment. In addition, it is also a very important issue in the successful management of forest genetic resources (Khanduri et al., 2013; Micheloud et al., 2018). For APNP, basic knowledge about the behaviour of the in-situ conserved flowering and fruiting plants would have a positive impact on wildlife in APNP considering the feed of various wild animals in APNP is very dependent on the presence of fruits in their habitat. In return, animals in APNP also helps the natural pollination of plants conserved.

The aims of this research were to find out the number, species, dominance, and abundance of flowering and fruiting plants in each APNP observation track, to figure out the comparison of flowering and fruiting plants in APNP and environmental factors affecting the flowering and fruiting plant periods in APNP. This study was expected to be the basic for plant management in supporting in-situ conservation in APNP.

\section{MATERIALS AND METHODS}

\section{Materials}

This study was conducted in Alas Purwo National Park, Tegaldlimo, Banyuwangi, East Java Indonesia, on 15 - 27 April 2019. Observation tracks of flowering and fruiting plants behaviour were forest plantation in Rowobendo, Trianggulasi beach, Birdwatching Track (JPB), Sadengan savanna, Parang Ireng beach, Pancur beach, Istana cave, Patirtan Mas, Moto Lele, Curah Kembang and Semar Moyo (Figure 1).

\section{Methods}

The method used was purposive random sampling in each observation track. Flowering and fruiting plants in each observation track were inventoried, documented and percentage scored by Arisoesilaningsih \& Soejono (2001), Hatta \& Darnaedi (2005), Anderson et al. (2005) and Handayani (2016). Environmental factors such as temperature, humidity, light intensity, soil $\mathrm{pH}$, elevation, and coordinates in each observation track were measured. Temperature and humidity were determined by using a thermohygrometer, light intensity by using a luxmeter, soil $\mathrm{pH}$ by using a $\mathrm{pH}$ meter, while elevation and coordinates by using a Garmin GPS. The observed parameters were the number and species of flowering and fruiting plants, the dominant number and plants in each observation track, the abundance of flowering and fruiting plants, comparison of flowering and fruiting plants, and the environmental factors affecting the flowering and fruiting behaviour. Species of flowering and fruiting plants in observation tracks were noted the number and its species. The dominant species number was counted in each observation track. The abundance of flowering and fruiting plants was counted by scoring method

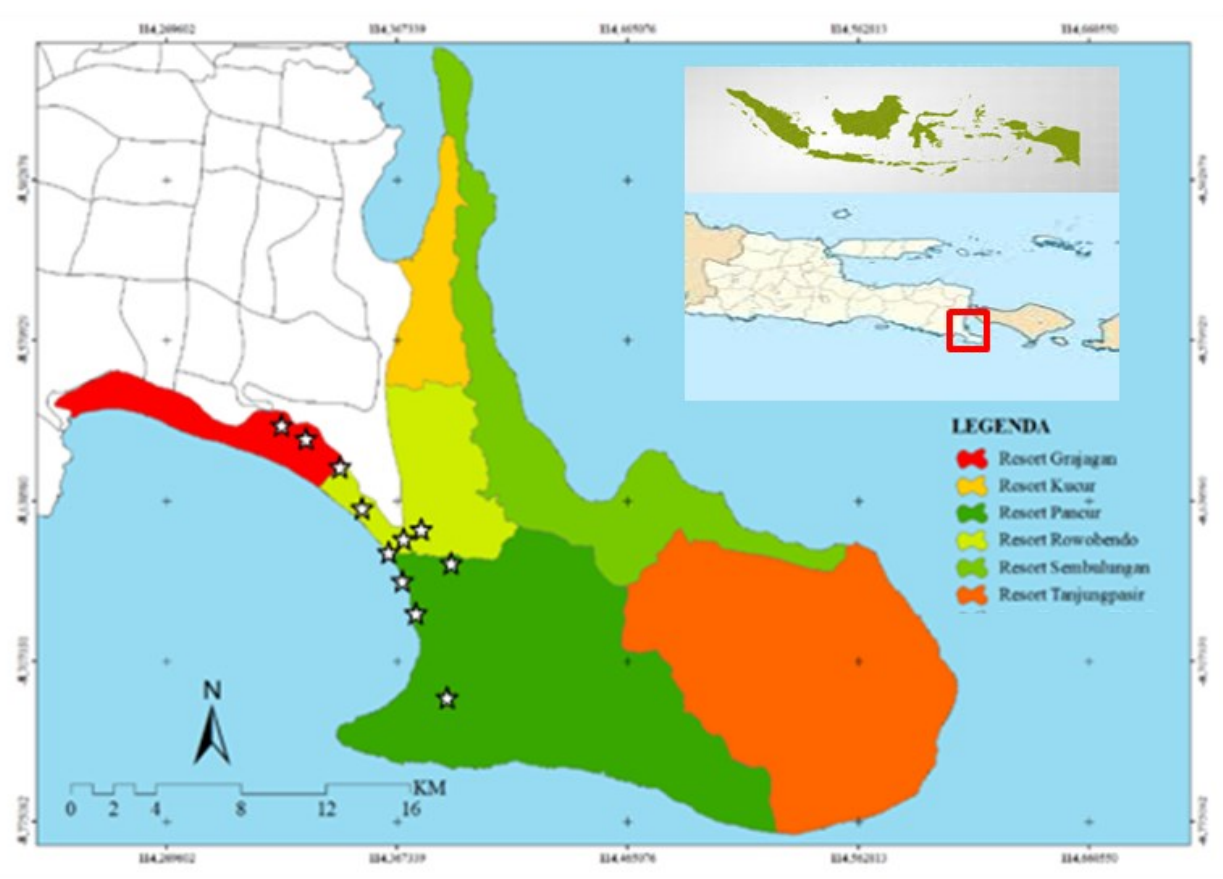

Figure 1. Research location in APNP, Banyuwangi, East Java, Indonesia (white star = observation track; ordinate: S $08^{\circ}$ $35^{\prime} 23.1^{\prime \prime}$ E $114^{\circ} 20^{\prime} 55.9^{\prime \prime}$ to S $08^{\circ} 43^{\prime} 26,1^{\prime \prime}$ E $\left.114^{\circ} 22^{\prime} 50.2^{\prime \prime}\right)$. 
(Anderson et al., 2005; Handayani, 2016; Lestari, 2019). Total from each flowering plant species compared with fruiting plant species in each observation track. The effect of environmental factors on flowering and fruiting behaviour was measured by analyzation of environmental factors data in each observation track using Principal Component Analysis (PCA) method.

Data were analyzed descriptively using Microsoft Excel and PAST 4.0. statistic program. PCA method was used to figure out the environmental factors affecting the plant flowering and fruiting behaviour in APNP.

\section{RESULTS AND DISCUSSION}

The behaviour of flowering and fruiting plants in each APNP observation track showed a unique characteristic. In several observation tracks, flowering and fruiting plants were dominated by one species, whereas in other tracks, those plants varied.

Number and species of flowering and fruiting plants in APNP

There were 90 flowering and fruiting plants within 45 families in APNP (Table 1). Flowering and fruiting plants varied in each observation track. Orophea enneandra, Polyalthia littoralis and Leea angulata were the most plants found flowering and fruiting in the study sites. The most flowering and fruiting plants found in the observation tracks were Euphorbiaceae.
Several plant species were found flowering and fruiting in each observation track. Flowering and fruiting plants found in more than 3 observation tracks were Chydenanthus excelcus, Corypha utan, Donax canniformis, Dysoxylum cyrtobotryum, Ficus hispida, Ficus montana, Harrisonia perforata, Leea angulata, Leea chinensis, Memecylon floribundum, Polyalthia littoralis, Spondias pinnata, Tacca palmata, Tetracera scandens, and Uvaria grandiflora. It indicated that those plants could easily adapt to their environment and had flowering and fruiting patterns throughout the year so that they were easy to find. Plants having the same pattern including Donax canniformis (Brink \& Escobin, 2003), Ficus hispida, and Ficus montana (Backer \& van den Brink, 1968), Orophea enneandra (Lestari, 2019), and Tetracera scandens (van Valkenburg \& Bunyapraphatsara, 2002). Some plants have an uncertain flowering season and it is mostly unaffected by climate such as Tacca palmata (Lemmens \& Bunyapraphatsara, 2003). Flowering season can also be influenced by pollinators, pollination types, and predators. Because flowering and fruiting behaviour were associated with biotic and climatic factors interaction (da Maia et al., 2013; Mohandass et al., 2018). Meanwhile, there are plants flowering and fruiting once or twice a year and the time is exactly the same as this research activity. For example, Dysoxylum cyrtobotryum in India flowers from February to April, while the fruits ripe from June to July (Kumar, 2009). As a result of climate differences in Indonesia, there may be a slight shift for fruit

Table 1. Flowering and fruiting plants in APNP.

\begin{tabular}{|c|c|c|c|c|c|c|c|c|c|c|c|c|}
\hline \multirow{2}{*}{ No } & \multirow{2}{*}{ Species } & \multicolumn{11}{|c|}{ Observation track } \\
\hline & & RWB & TRB & JPB & SS & PIB & PCB & IC & $\mathbf{P M}$ & ML & CK & SM \\
\hline 1 & $\begin{array}{l}\text { Aglaonema simplex (Blume) } \\
\text { Blume }\end{array}$ & & & + & & & & & & & & \\
\hline 2 & $\begin{array}{l}\text { Aleurites moluccanus (L.) } \\
\text { Willd. }\end{array}$ & & & & & & & & + & & & \\
\hline 3 & $\begin{array}{l}\text { Allophyllus cobbe (L.) Rae- } \\
\text { usch. }\end{array}$ & + & & & & + & & & & & & \\
\hline 4 & $\begin{array}{l}\text { Alocasia gigantean (Schott) } \\
\text { G.Don }\end{array}$ & & + & & & & & & & & & \\
\hline 5 & Alstonia spectabilis R.Br. & + & & & & & & & & & & \\
\hline 6 & $\begin{array}{l}\text { Antidesma bunius (L.) } \\
\text { Spreng }\end{array}$ & & & & & + & & & & & & \\
\hline 7 & Antidesma montanum Blume & & & + & & & & & & & + & \\
\hline 8 & $\begin{array}{l}\text { Archidendron bigeminum (L.) } \\
\text { I.C.Nielsen }\end{array}$ & & & & & & & + & & & & \\
\hline 9 & Ardisia elliptica Thunb. & & & & & & & & & + & & \\
\hline 10 & Ardisia bumilis Vahl. & & & & & + & & & & & & \\
\hline 11 & Ardisia sp. & & & & & & & & + & & & \\
\hline 12 & Arytera serrata & & + & & & & & & & & & \\
\hline 13 & Bambusa blumeana Schult.f. & & & & & & & & & + & & \\
\hline 14 & Bischofia javanica Blume & & & + & & & & & + & & & \\
\hline 15 & Calophyllum inophyllum L. & + & & & & & & & & & & \\
\hline
\end{tabular}


Table 1. Contd.

\begin{tabular}{|c|c|c|c|c|c|c|c|c|c|c|c|c|}
\hline \multirow{2}{*}{ No } & \multirow{2}{*}{ Species } & \multicolumn{11}{|c|}{ Observation track } \\
\hline & & RWB & TRB & JPB & SS & PIB & PCB & IC & $\mathbf{P M}$ & ML & CK & SM \\
\hline 16 & Canarium hirsutum Willd. & & & + & & & & & & & & \\
\hline 17 & Canavalia rosea (Sw.) DC. & + & & & & & & & & & & \\
\hline 18 & $\begin{array}{l}\text { Carapichea ipecacuanha } \\
\text { (Brot.) L. Andersson }\end{array}$ & & & & & & & + & & + & & \\
\hline 19 & Casearia grewiïfolia Vent. & & + & & & & & & & & & \\
\hline 20 & Cassia fistula L. & & & & & & & & + & & & \\
\hline 21 & Randia sp. & & & & & & & & & + & & \\
\hline 22 & Cerbera odollam Gaertn. & & + & & & & & & & & & \\
\hline 23 & $\begin{array}{l}\text { Cheilocostus speciosus } \\
\text { (J.Koenig) C.D. Specht }\end{array}$ & & & & + & & & & + & & & \\
\hline 24 & $\begin{array}{l}\text { Chydenanthus excelcus } \\
\text { (Blume) Miers }\end{array}$ & & & & + & & & & + & + & + & \\
\hline 25 & $\begin{array}{l}\text { Cleistanthus collinus (Roxb.) } \\
\text { Benth. ex Hook.f. }\end{array}$ & & & & + & & & & & & & \\
\hline 26 & Corypha utan Lam. & & & & + & & + & + & & + & & \\
\hline 27 & Crotalaria juncea L. & & & & & & & & & + & & \\
\hline 28 & Diospyros cauliflora Blume & & & & & & & & + & & + & \\
\hline 29 & Diospyros maritima Blume & & & & & + & & & & & & \\
\hline 30 & $\begin{array}{l}\text { Diospyros vera (Lour.) } \\
\text { A.Chev. }\end{array}$ & & & & + & & & & & & & \\
\hline 31 & $\begin{array}{l}\text { Donax canniformis } \\
\text { (G.Forst.) K.Schum. }\end{array}$ & & & & + & & & + & + & & + & \\
\hline 32 & $\begin{array}{l}\text { Dovyalis caffra (Hook.f. \& } \\
\text { Harv.) Sim }\end{array}$ & & & & + & & & & & + & & \\
\hline 33 & $\begin{array}{l}\text { Dracaena angustifolia } \\
\text { (Medik.) Roxb. }\end{array}$ & & & & & + & & & & & & \\
\hline 34 & $\begin{array}{l}\text { Drypetes serrata (Maycock) } \\
\text { Krug \& Urb. }\end{array}$ & & & & & & & & & + & & \\
\hline 35 & $\begin{array}{l}\text { Dysoxylum cyrtobotryum } \\
\text { Miq. }\end{array}$ & & + & + & & + & & & & & & \\
\hline 36 & Embelia ribes Burm.f. & & & + & & & & & & & & \\
\hline 37 & Ficus racemosa L. & + & & & & & + & & & & & \\
\hline 38 & Ficus callophylla Blume (1) & + & & & & & & & & & + & \\
\hline 39 & Ficus callophylla Blume (2) & & & & + & & & & & & & \\
\hline 40 & Ficus callosa Willd. & & & & & & & & & + & & \\
\hline 41 & Ficus drupacea Thunb. & & & & & & & & & + & & \\
\hline 42 & Ficus hispida L.f. & + & & & & + & & & + & + & & \\
\hline 43 & Ficus montana Burm.f. & & & & + & & & + & + & & + & \\
\hline 44 & Ficus variegata Blume & & & + & & & & + & & & & \\
\hline 45 & Gnetum gnemon L. & & & & & + & & & & & & \\
\hline 46 & Grewia asiatica $\mathrm{L}$ & & & & & & & & & + & & \\
\hline 47 & $\begin{array}{l}\text { Harpullia arborea (Blanco) } \\
\text { Radlk. }\end{array}$ & & & & & & & & & + & & \\
\hline 48 & $\begin{array}{l}\text { Harrisonia perforata } \\
\text { (Blanco) Merr. }\end{array}$ & & & & + & & & & + & + & + & \\
\hline 49 & $\begin{array}{l}\text { Hernandia nymphaeifolia } \\
\text { (J.Presl) Kubitzki }\end{array}$ & + & & & & + & & & & & & \\
\hline 50 & $\begin{array}{l}\text { Ipomoea pes-caprae (L.) R. } \\
\text { Br. }\end{array}$ & + & & & & & & & & & & \\
\hline
\end{tabular}


Table 1. Contd.

\begin{tabular}{|c|c|c|c|c|c|c|c|c|c|c|c|c|}
\hline \multirow{2}{*}{ No } & \multirow{2}{*}{ Species } & \multicolumn{11}{|c|}{ Observation track } \\
\hline & & RWB & TRB & JPB & $\mathrm{SS}$ & PIB & PCB & IC & PM & ML & CK & $\overline{\mathbf{S M}}$ \\
\hline 51 & Ixora smeruensis Bremek. & & + & & & & & & & & & \\
\hline 52 & Ixora sp. & & & & & & & + & & & & \\
\hline 53 & Knema cinerea (Poir.) Warb. & & & & & & & & + & & + & \\
\hline 54 & Lantana camara $\mathrm{L}$ & & & & + & & & & & + & & \\
\hline 55 & $\begin{array}{l}\text { Leea angulata Korth. ex } \\
\text { Miq. }\end{array}$ & + & + & + & + & & & & + & + & & \\
\hline 56 & Leea chinensis & & + & + & + & & & & & & & \\
\hline 57 & $\begin{array}{l}\text { Mallotus dispar (Blume) } \\
\text { Mull.Arg. }\end{array}$ & & & & & & & & & + & & \\
\hline 58 & Mallotus sp. & & & & & + & & & & & & \\
\hline 59 & Memecylon floribundum Blume & & & + & & & & + & & + & & \\
\hline 60 & Mimosa pudica L. & & & & & + & & & & & & \\
\hline 61 & Musa acuminata Colla & & & & & & & & + & & & \\
\hline 62 & Nauclea sp. & & & & & & & & & + & & \\
\hline 63 & Nicolaia sp. & & & & & & & & & + & & \\
\hline 64 & $\begin{array}{l}\text { Ochrosia ackeringae (Teijsm. } \\
\text { \& Binn.) Miq. }\end{array}$ & & + & & & & & & & & & \\
\hline 65 & $\begin{array}{l}\text { Oplismenus burmanni (Retz.) } \\
\text { P.Beauv. }\end{array}$ & & & & & + & & & & & & \\
\hline 66 & Orophea enneandra Blume & & & + & & & & + & + & & + & \\
\hline 67 & Palaquium sp. & & & & & & & & & & + & \\
\hline 68 & Pangium edule Reinw. & & & & & & & & + & & & \\
\hline 69 & Pavetta indica $\mathrm{L}$ & & & & & & & & & + & & \\
\hline 70 & Phaleria capitata Jack. & & & + & & & & & + & + & & \\
\hline 71 & Physalis angulata L. & & & & & + & & & & & & \\
\hline 72 & Piper cubeba L.f. & + & & & & & & & & + & & \\
\hline 73 & Piper retrofractum Vahl. & + & & & & & & & & & & \\
\hline 74 & $\begin{array}{l}\text { Polyalthia littoralis (Blume) } \\
\text { Boerl. }\end{array}$ & & & + & & & & + & & + & & \\
\hline 75 & $\begin{array}{l}\text { Sandoricum koetjape } \\
\text { (Burm.f.) Merr. }\end{array}$ & & & & & & & & & & & + \\
\hline 76 & $\begin{array}{l}\text { Pseuderanthemum carruthersii } \\
\text { (Seem.) Guillaumin }\end{array}$ & & & & & + & & & & + & & \\
\hline 77 & $\begin{array}{l}\text { Senna siamea (Lam.) H.S. } \\
\text { Irwin \& Barneby }\end{array}$ & + & & & & & + & & & & & \\
\hline 78 & Spondias pinnata (L.f.) Kurz. & & & + & & & & & + & & + & \\
\hline 79 & Sterculia foetida $\mathrm{L}$ & & + & & & & & & & + & & \\
\hline 80 & $\begin{array}{l}\text { Suregada glomerulata (Blume) } \\
\text { Baill. }\end{array}$ & + & & & & & & & & & & \\
\hline 81 & $\begin{array}{l}\text { Tabernaemontana pandacaqui } \\
\text { Lam. }\end{array}$ & + & & & & & & & & & & \\
\hline 82 & $\begin{array}{l}\text { Tabernaemontana sphaerocarpa } \\
\text { Blume }\end{array}$ & & & & & & & & & & + & \\
\hline 83 & Tabernaemontana sp. & & & & + & & & & & & & \\
\hline 84 & $\begin{array}{l}\text { Tacca leontopetaloides (L.) } \\
\text { Kuntze }\end{array}$ & & & & & & & & & + & & \\
\hline 85 & Tacca palmata Blume & & & + & + & & & + & & & & \\
\hline
\end{tabular}


Table 1. Contd.

\begin{tabular}{|c|c|c|c|c|c|c|c|c|c|c|c|c|}
\hline \multirow{2}{*}{ No } & \multirow{2}{*}{ Species } & \multicolumn{11}{|c|}{ Observation track } \\
\hline & & RWB & TRB & JPB & SS & PIB & PCB & IC & $\mathbf{P M}$ & ML & CK & SM \\
\hline 86 & $\begin{array}{l}\text { Tetracera scandens (L.) } \\
\text { Merr. }\end{array}$ & & & + & + & & & & & + & & \\
\hline 87 & $\begin{array}{l}\text { Uvaria grandiflora Roxb. } \\
\text { ex Hornem }\end{array}$ & & & + & + & & & & & + & & \\
\hline 88 & $\begin{array}{l}\text { Voacanga grandifolia } \\
\text { (Miq.) Rolfe }\end{array}$ & + & & & & & & & & & & \\
\hline 89 & Vitex pinnata L. & & & & + & & + & & & & & \\
\hline 90 & Vitis sp. & & & & & & & & & + & & \\
\hline
\end{tabular}

Note: RWB $=$ Rowobendo Forest Plantation, TRB $=$ Trianggulasi Beach, JPB $=$ Birdwatching Track, $\mathrm{SS}=$ Sadengan Savanna, PIB = Parang Ireng Beach, PCB = Pancur Beach, IC = Istana Cave, PM = Patirtan Mas, $\mathrm{ML}=$ Moto Lele, $\mathrm{CK}=$ Curah Kembang, $\mathrm{SM}=$ Semar Moyo.

ripening i.e. in April. Polyaltbia littoralis which is exsitu conserved in Purwodadi Botanic Garden and resulting from plant exploration activity in APNP, have twice a year flowering pattern and once a year fruiting pattern, from January to August (Handayani, 2016; Lestari, 2019). Uvaria grandiflora has a fruiting period from January to May (Lestari, 2019) in Purwodadi Botanic Garden. Spondias pinnata in southeastern India has a fruiting period from June to November, and probably due to the different seasons, it has an earlier fruiting period in May. Some species of Spondias fruit in May or approaching May in the tropics (Mitchell \& Daly, 2015). Corypha utan has flowering and fruiting period only once i.e. at the end of its life (Heyne, 1987).

The dominant plants and their number in each observation track

The observation track with the most flowering and fruiting plants was Moto Lele (20\%), followed by Patirtan Mas and Sadengan savanna (12\%) (Figure 2). The dominant flowering and fruiting plants in each observation track varied. The dominant flowering and fruiting plants in Rowobendo Forest Plantation were Piper cubeba, Piper retrofractum (fruiting), and Suregada glomerulata (flowering and fruiting). Casearia grewiifolia was only found fruiting on the edge of Trianggulasi beach. Orophea enneandra was found fruiting in Bird Watching Path (JPB), Istana Cave (flowering), Patirtan Mas, and Curah Kembang. Two species were found fruiting in two different locations, namely Leea angulata in Sadengan savanna and Moto Lele, and Polyalthia littoralis in JPB and Moto Lele. Ficus hispida and Diospyros maritima were found fruiting along the Parang Ireng beach. On the edge of Pancur beach, many Corypha utan were found fruiting. Besides Orophea enneandra, Tacca palmata and Ficus montana were found fruiting in the Istana cave. Bambusa blumeana was also found blooming in Moto Lele, besides Polyalthia littoralis and
Leea angulata that were fruiting (Figure 3). There was no dominant flowering and fruiting plants in Semar Moyo.

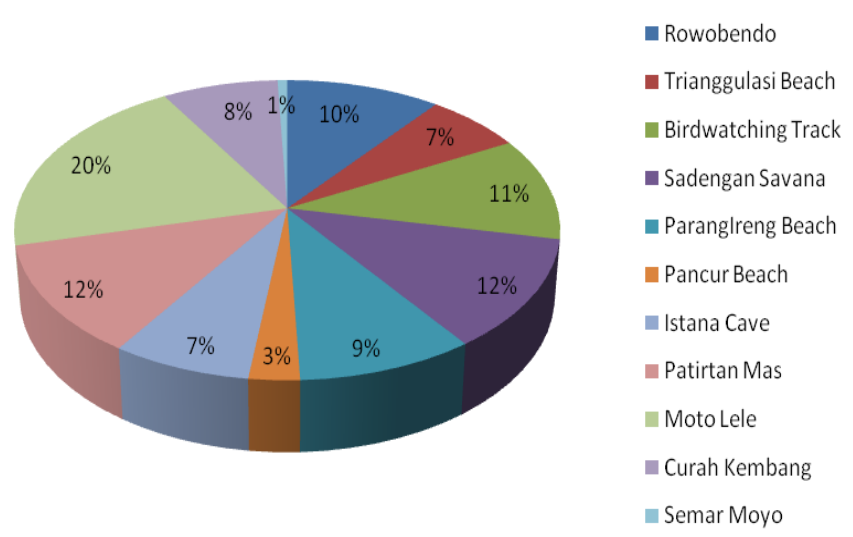

Figure 2. The percentage of flowering and fruiting plants in each observation track.

Flowering and fruiting plants in Moto Lele were more numerous than other observation tracks. It was because it had warm air temperature $\left(32.34^{\circ}\right.$ C), medium level of humidity (65.2\%), and light intensity (665.28 lux) to support the process of plant metabolism. Therefore, it was more optimal for flower and fruit formation than others. Sufficient light intensity affects the level of photosynthesis as the source of energy for the flowering process. Denser vegetation canopy in other observation tracks causes less light intensity hence the growth and development of fruit would not be optimized. Low light intensity is closely related to PAR (Photosynthetically Active Radiation), where the denser canopy level causes low PAR value and vice versa. Plants experience a double decline in fruit production under low light intensity, which is closely related to the distribution of carbon to the fruit and influenced by the balance between starch and sucrose (Sitompul, 2010). Moto Lele was a type of natural forest with fairly dense vegetation canopy 


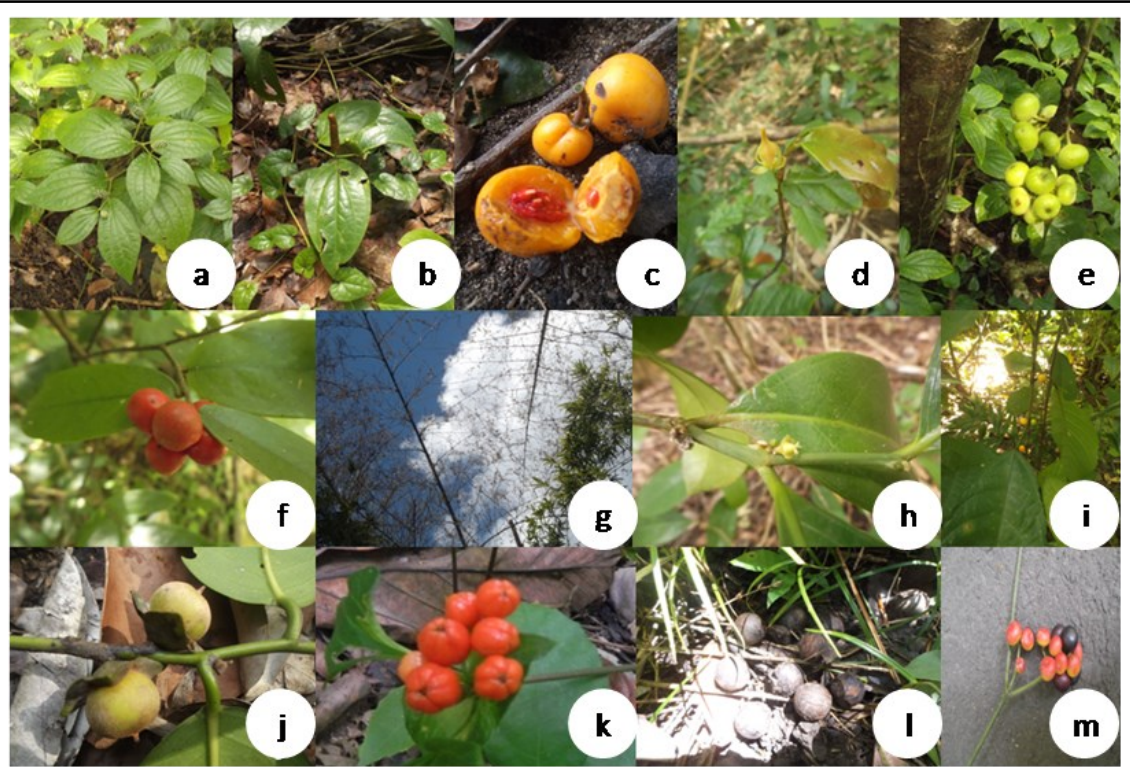

Figure 3. The dominant flowering and fruiting plants in APNP; a. Immature fruit of Piper cubeba, b. Ripe fruit of Piper retrofractum, c. Ripe fruit of Casearia grewiifolia, d. flower of Orophea enneandra, e. Immature fruit of Ficus hispida, f. Mature fruit of Polyathia littoralis, g. Blooming of Bambusa blumeana, h. Blooming of Suregada glomerulata, i. Mature fruit of Ficus montana, j. Immature fruit of Diospyros maritima, k. Mature fruit of Tacca palmata, l. Mature fruit of Corypha utan, m. Mature fruit of Leea angulata percentage of flowering and fruiting plants.

and still relatively native (Darmayanti et al., 2019). Thus, it became the preferred habitat for butterflies. The butterflies found in APNP were 39 species and some of them were classified as pollinators (Budiarto, 2014). Besides that, there found vulnerable bird species such as Leptoptilos javanicus and Pavo muticus in Sadengan savanna as a representation of ideal place to take a rest and to forage (Widodo, 2016). There are 13 bats species with 2 Near Threatened species playing role as zoopollinator known to be scattered in the cave area of APNP (Rianti et al., 2009). The number of zoopollinator living in forest areas certainly influences the number of pollinated plants and thus the number of fruiting plants.

The abundance of flowering and fruiting plants The abundance of flowering and fruiting plants in each observation track was shown in Figure 4. Species with the greatest abundance in each observation track were Calophyllum inophyllum in Rowobendo Plantation Forest, Tacca palmata in Istana cave, and Corypha utan in Moto Lele.

Comparison of flowering and fruiting plants number

Based on Figure 5, it can be inferred that the number of fruiting plants in each observation track

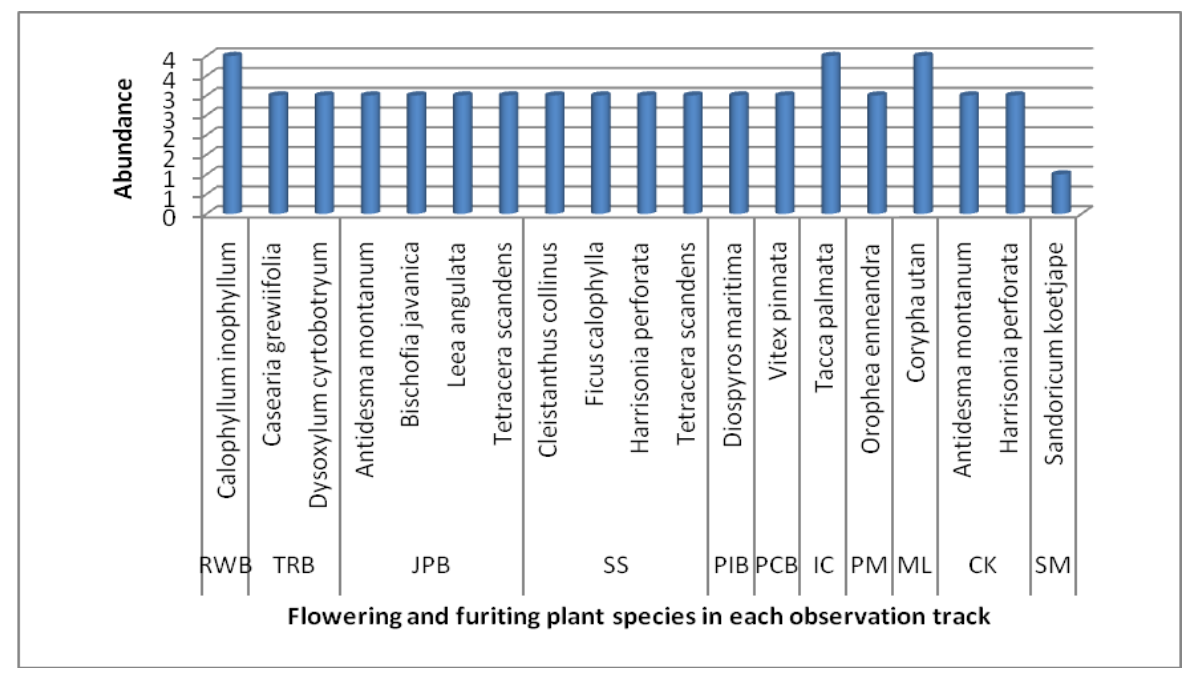

Figure 4. The abundance of flowering and fruiting plants in each observation track; RWB $=$ Forest Plantation of Rowobendo, TRB = Trianggulasi Beach, JPB = Birdwatching Track, SS = Sadengan Savanna, PIB = Parang Ireng Beach, $\mathrm{PCB}=$ Pancur Beach, $\mathrm{IC}=$ Istana Cave, $\mathrm{PM}=$ Patirtan Mas, $\mathrm{ML}=$ Moto Lele, $\mathrm{CK}=$ Curah Kembang, $\mathrm{SM}=$ Semar Moyo. 
is more than flowering ones. Even in JPB, Curah Kembang, and Semar Moyo, there were no flowering plants found. Observation tracks where flowering plants were mostly found in Moto Lele, followed by Sadengan savanna and Parang Ireng beach. While fruiting plants were mostly found in Moto Lele, followed by Patirtan Mas and JPB.

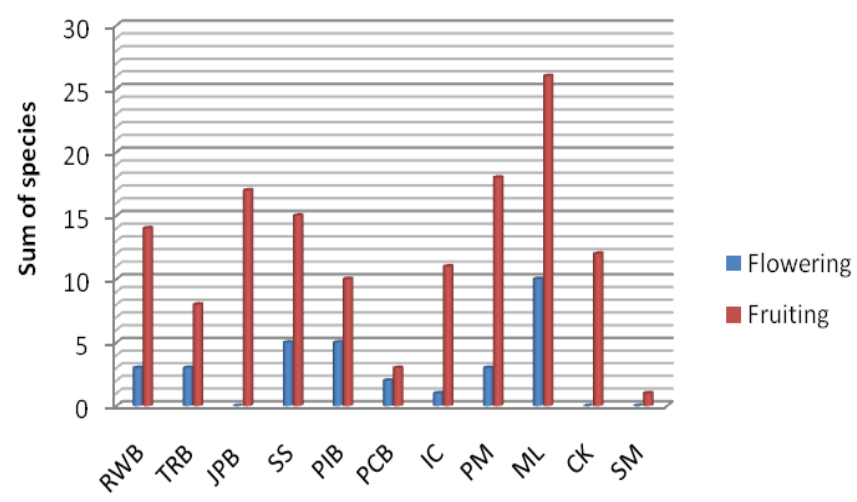

Figure 5. Comparison of flowering and fruiting plants number in each observation track; RWB = Forest Plantation of Rowobendo, TRB = Trianggulasi Beach, $\mathrm{JPB}=$ Birdwatching Track, SS = Sadengan Savanna, PIB $=$ Parang Ireng Beach, $\mathrm{PCB}=$ Pancur Beach, $\mathrm{IC}=$ Istana Cave, $\mathrm{PM}=$ Patirtan Mas, $\mathrm{ML}=$ Moto Lele, $\mathrm{CK}=$ Curah Kembang, $\mathrm{SM}=$ Semar Moyo.

The numbers of fruiting plants were more than the flowering ones. According to Anderson et al. (2005), the peak of the flowering season in tropics usually in the wet season. Meanwhile, this research was carried out during the dry season, so that the number of flowering plants was less than the fruiting ones. Flowering initiation is influenced by external factors such as environment and also stimulated by endogenous factors such as hormonal factors, flowering time initiation, and an adequate carbon or nitrogen balance (Larcher, 1995). During the dry season, immature fruits are formed immediately after the flowers bloom. Immature fruits take several months to become ripe fruits (Arisoesilaningsih et al., 2001).

Influence of environmental factors on flowering and fruiting behaviour

Based on Table 2, range of general environmental conditions in the observation track were $29.8-32.34^{\circ}$ C (temperature), 65.2 - 77.88\% (humidity), 21.7-73 $\mathrm{m}$ asl (elevation), 6-7 (soil pH), 83.2-2306.75 lux (light intensity) and the coordinates location was between S $08^{\circ} 35^{\prime} 23.1^{\prime \prime} \mathrm{E} 114^{\circ} 20^{\prime} 55.9^{\prime \prime}$ to S $08^{\circ}$ $43^{\prime 2} 26,1^{\prime \prime}$ E $114^{\circ} 22^{\prime} 50.2^{\prime \prime}$. The influence of environmental factors on the number of flowering and fruiting plants was shown in Figure 6.

Temperature and light intensity were the two most influential factors of the flowering and fruiting period in APNP, especially in Rowobendo Plantation Forest, JPB, Sadengan savanna, Parang Ireng beach, Istana cave, and Moto Lele. The numbers of flowering and fruiting plants found in those observation tracks were more compared to other regions.

Environmental factors influencing the plants to flower are humidity, temperature, sunlight, rainfall, and nutrients (Sulistyawati et al., 2012). Based on Figure 6, temperature and light intensity are environmental factors affecting the behaviour of flowering and fruiting plants found in observation tracks. Microclimate is the most important factor and has a significant effect on flowering and fruiting

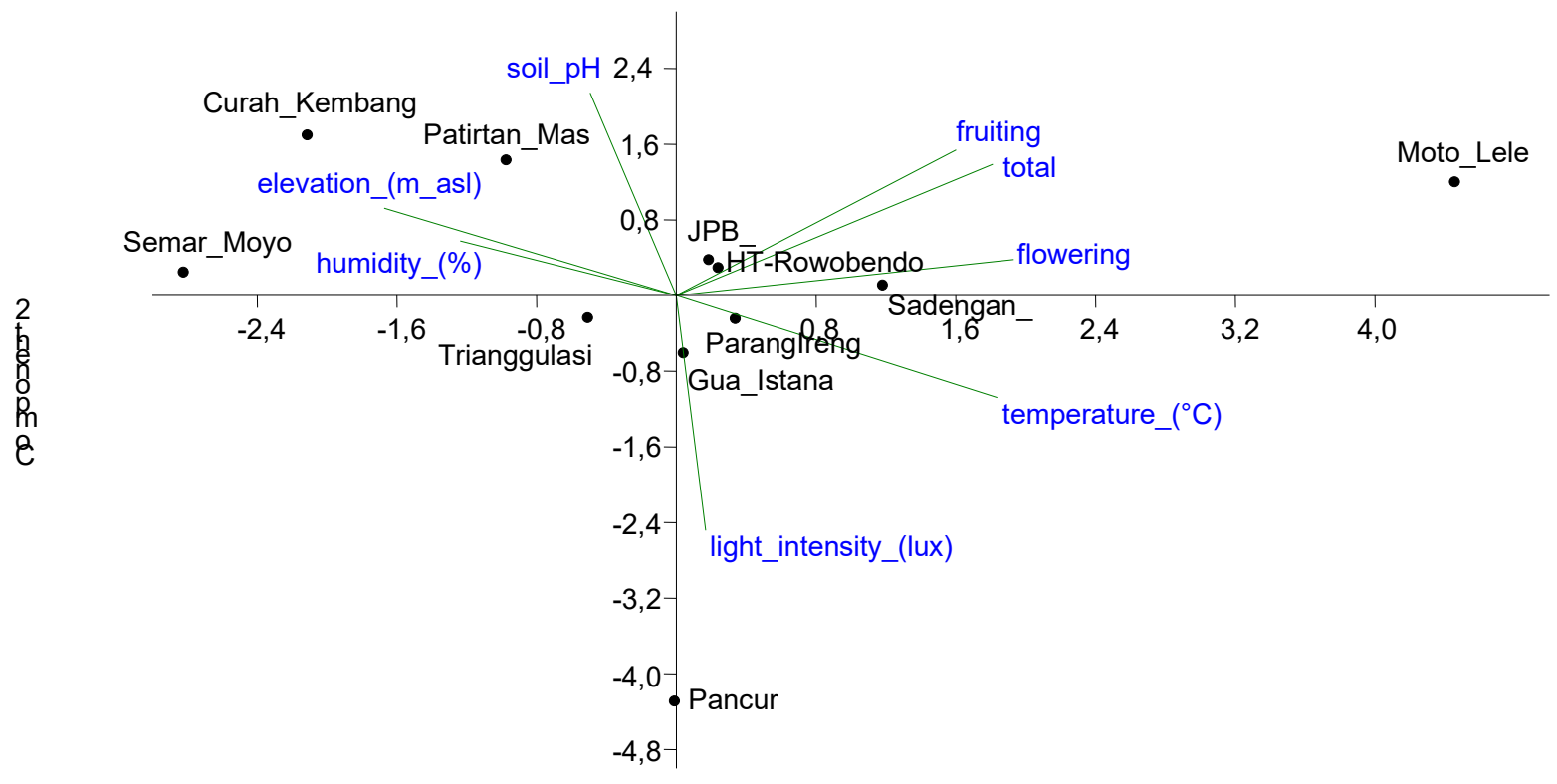

Component 1

Figure 6. Effect of microclimate factors on flowering and fruiting plants in APNP. 
Table 2. Average of microclimate factors in each observation track; RWB $=$ Forest Plantation of Rowobendo, $\mathrm{TRB}=$ Trianggulasi Beach, JPB = Birdwatching Track, SS = Sadengan Savanna, PIB = Parang Ireng Beach, PCB = Pancur Beach, $\mathrm{IC}=$ Istana Cave, $\mathrm{PM}=$ Patirtan Mas, $\mathrm{ML}=$ Moto Lele, $\mathrm{CK}=$ Curah Kembang, $\mathrm{SM}=$ Semar Moyo.

\begin{tabular}{|c|c|c|c|c|c|c|c|c|c|}
\hline \multirow[b]{2}{*}{$\begin{array}{l}\text { Observat } \\
\text { ion track }\end{array}$} & \multicolumn{6}{|c|}{ Average of microclimate factors } & \multicolumn{2}{|c|}{ Sum of species } & \multirow[b]{2}{*}{ Total } \\
\hline & $\begin{array}{l}\text { Tempe } \\
\text { rature } \\
\left({ }^{\circ} \mathrm{C}\right)\end{array}$ & $\begin{array}{l}\text { Humidity } \\
(\%)\end{array}$ & $\begin{array}{l}\text { Elevation } \\
\text { (m asl) }\end{array}$ & $\begin{array}{l}\text { Soil } \\
\mathrm{pH}\end{array}$ & $\begin{array}{l}\text { Light } \\
\text { intensity } \\
\text { (lux) }\end{array}$ & Coordinate & Flowering & Fruiting & \\
\hline RWB & 30.75 & 74.4 & 29.6 & 6.67 & 937.56 & $\begin{array}{l}\text { S } 08^{\circ} 38^{\prime} 24,6^{\prime \prime} \\
\text { E } 114^{\circ} 20^{\prime} 55,9^{\prime \prime} \\
- \\
\text { S083’ } 40,8^{\circ} \\
\text { E } 114^{\circ} 21^{\prime} 23,7^{\prime \prime}\end{array}$ & 3 & 14 & 16 \\
\hline TRB & 30.7 & 75.5 & 26.13 & 6.68 & 1181.13 & $\begin{array}{l}\text { S } 08^{\circ} 39^{\prime} 00,0^{\prime \prime} \\
\text { E } 114^{\circ} 21^{\prime} 39,5^{\prime \prime} \\
- \\
\text { S08 } 39^{\prime} 22,7^{\prime \prime} \\
\text { E } 114^{\circ} 21^{\prime} 43^{\prime \prime}\end{array}$ & 3 & 8 & 10 \\
\hline JPB & 31.32 & 74.07 & 33.21 & 6.59 & 591.58 & $\begin{array}{l}\text { S } 08^{\circ} 39^{\prime} 11,1^{\prime \prime} \\
\text { E } 114^{\circ} 21^{\prime} 52,6 " \\
- \\
\text { S0839'35,3” } \\
\text { E } 114^{\circ} 22^{\prime} 03,9 ”\end{array}$ & 0 & 17 & 17 \\
\hline SS & 30.9 & 69.88 & 27 & 6.6 & 1193.75 & $\begin{array}{l}\text { S } 08^{\circ} 39^{\prime} 05,7^{\prime \prime} \\
\text { E } 114^{\circ} 22^{\prime} 00,8^{\prime \prime} \\
- \\
\text { S0839'13,9” } \\
\text { E } 114^{\circ} 22^{\prime} 18,3^{\prime \prime}\end{array}$ & 5 & 15 & 18 \\
\hline PIB & 30.48 & 70.5 & 28.25 & 6.75 & 2306.75 & $\begin{array}{l}\text { S } 08^{\circ} 41^{\prime} 05,6^{\prime \prime} \\
\text { E } 114^{\circ} 22^{\prime} 30,3^{\prime \prime} \\
- \\
\text { S0 } \\
\text { E } 118^{\circ} 41^{\circ} 07,2^{\prime} 31,7^{\prime \prime}\end{array}$ & 5 & 10 & 14 \\
\hline PCB & 31.7 & 71 & 30 & 6 & 6200 & $\begin{array}{l}\text { S } 08^{\circ} 40^{\prime} 42,3^{\prime \prime} \\
\text { E } 114^{\circ} 22^{\prime} 27,2^{\prime \prime}\end{array}$ & 2 & 3 & \\
\hline IC & 31.42 & 68.4 & 43.6 & 6.56 & 1156.15 & $\begin{array}{l}\text { S } 08^{\circ} 40^{\prime} 17,7^{\prime \prime} \\
\text { E } 114^{\circ} 22^{\prime} 27,2^{\prime \prime} \\
- \\
\text { S08 } 48^{\circ} 42,3^{\prime \prime} \\
\text { E } 114^{\circ} 22^{\prime} 46,8^{\prime \prime}\end{array}$ & 1 & 11 & 11 \\
\hline PM & 30.06 & 77.88 & 70.88 & 6.56 & 544.1 & $\begin{array}{l}\text { S } 08^{\circ} 37^{\prime} 53,4^{\prime \prime} \\
\text { E } 114^{\circ} 22^{\prime} 32,4^{\prime \prime} \\
- \\
\text { S08 } \\
\text { E } 118^{\circ} 22^{\circ} 02,9^{\prime}, \\
\end{array}$ & 3 & 18 & 18 \\
\hline ML & 32.34 & 65.2 & 21.7 & 6.78 & 665.28 & $\begin{array}{l}\text { S } 08^{\circ} 42^{\prime} 29,6^{\prime \prime} \\
\text { E } 114^{\circ} 22^{\prime} 14,3^{\prime \prime} \\
- \\
\text { S0843’26,1” } \\
\text { E } 114^{\circ} 22^{\prime} 34,7^{\prime \prime}\end{array}$ & 10 & 26 & 31 \\
\hline $\mathrm{CK}$ & 29.8 & 76 & 62 & 7 & 83.2 & $\begin{array}{l}\text { S } 08^{\circ} 35^{\prime} 23,1^{\prime \prime} \\
\text { E } 114^{\circ} 22^{\prime} 05,0^{\prime \prime}\end{array}$ & 0 & 12 & 12 \\
\hline SM & 30.1 & 69 & 73 & 7 & 624 & $\begin{array}{l}\text { S } 08^{\circ} 36^{\prime} 39,1^{\prime \prime} \\
\text { E } 114^{\circ} 22^{\prime} 19,8^{\prime \prime}\end{array}$ & 0 & 1 & 1 \\
\hline
\end{tabular}

periods compared to height and location (Panchen, 2016).

Time or period is an important component in plant reproduction. Individual plants with early flowering would have a limited capacity to produce fruit (Milla et al., 2006; Khanduri, 2014). Certain plants produce fruits from flowers in a very short period, but other plants require a longer time. This behaviour is very important and useful in planning the conservation improvement programs and strategies for a plant species. The need to recognize the flowering and fruiting behaviour of a plant species and observe its phenological development is very closely related to its ecological studies (Augspurger, 1983; Abu-Asab et al., 2001). In addition, the study of flowering and fruiting plant 
behaviour is important from the perspective of genetic resources conservation and conservation areas management (Omondi et al., 2016). Especially for in-situ conservation areas, such as APNP, where fauna becomes one of the important components in its ecosystem. Flowering plants provide many benefits, beside become food sources, they also become places to lay eggs, hiding, and inviting other fauna species in the ecosystem such as pollinators, natural enemies, as well as other ecological functions. Through flowering and fruiting plants, the ecosystem would be more stable, thus the ecosystem components balance could be maintained (Kurniawati \& Martono, 2015).

\section{CONCLUSION}

There were 90 species of flowering and fruiting plants in APNP from 45 families. Most species often found flowering and fruiting were Orophea enneandra, Polyalthia littoralis, and Leea angulata which were scattered in Moto Lele, Patirtan Mas, and Sadengan Savanna. Fruiting plants species were more often found than flowering ones. Temperature and light intensity became the two most affecting environmental factors on flowering and fruiting plants behaviour.

\section{ACKNOWLEDGMENTS}

This research was financially supported by Indonesian the Institute of Sciences through seed bank research program. We would like to acknowledge the Director of Research Center for Plant Conservation and Botanic Garden, the Director of Purwodadi Botanic Garden for the opportunity to conduct field activities, the Director of Alas Purwo National Park, Alas Purwo National Park team for their assistance in the field, Mr. Achmad Suef for his assistance in the field for plant identification and other technical assistance, and Elok Rifqi Firdiana for her assistance in checking the English spelling and grammar. For author contribution, DAL is the main author.

\section{REFERENCES}

Abu-Asab, M.S., Peterson, P.M., Shetler, S.G., \& Orli, S.S., 2001, Earlier plant flowering in spring as a response to global warming in the Washington, DC, area, Biodivers Conserv 10(4), 597-612.

Anderson, D.P., Nordheim, E.V., Moermond, T.C., Gone Bi, Z.B., \& Boesch, C., 2005, Factors influencing tree phenology in Ta'i National Park, BIOTROPICA 37(4), 631-640, DOI 10.1111/j.1744-7429.2005.00080.x.
Arisoesilaningsih, E., \& Soejono, 2001, Purwodadi Botanic Garden is a dry climate hortus?, Proceeding of National Seminary on Conservation and Utilization of Dry Lowland Plant Diversity, Purwodadi Botanic Garden Indonesian Institute of Sciences and Brawijaya University, Pasuruan.

Arisoesilaningsih, E., Soejono, Widyati, A., Palupi, I., \& Kiswojo, 2001, Reproductive activities of three an endangered tree lowland species in Purwodadi Botanic Garden, Proceeding of National Seminary on Conservation and Utilization of Dry Lowland Plant Diversity, Purwodadi Botanic Garden - Indonesian Institute of Sciences and Brawijaya University, Pasuruan.

Augspurger, C.K., 1983, Phenology, flowering synchrony, and fruit set of six neotropical shrubs, Biotropica 15(4), 257-267.

Backer, C.A., \& van den Brink, R.C.B., 1968, Flora of Java, Third Edition, Noordhoff Groningen, The Netherlands.

Brink, M., \& Escobin, R.P., 2003, Donax canniformis, Plant Resources of South East Asia No 17. Fibre Plants, Prosea Foundation, Bogor.

Budiarto, E., 2014, Inventory of Butterflies (Lepidoptera: Rhopalocera) in Pancur Resort, Alas Purwo National Park, Banyuwangi, East Java, Thesis, Department of Biology, Faculty of Mathematic and Natural Sciences, University of Jember, Jember.

Da Maia, F.R., Malucelli, T.S., \& Varassin, I.G., 2013, Ecological factors affecting the fruiting success of a Tibouchina trichopoda (DC.) Baill. (Melastomataceae) flower, Acta Bot. Bras. 27(1): 142 $-146$.

Darmayanti, A.S., Lestari, D.A., \& Suef, A., 2019, Report of Seed Collection Activities in Alas Purwo National Park for the Development of Purwodadi Botanic Garden Seed Bank, Purwodadi Botanic Garden-LIPI, Pasuruan.

Goldsworthy, P.R., \& Fisher, N.M., 1992, Physiology of Tropical Cultivated Plants, Gadjah Mada University Press, Yogyakarta.

Handayani, T., 2016, Flowering and fruiting time of Annonaceae species in Bogor Botanic Gardens, Buletin Kebun Raya 19(2), 91-104.

Hatta, H., \& Darnaedi, D., 2005, Phenology and Growth Habits of Tropical Trees: Long Term Observations in the Bogor and Cibodas Botanic Gardens, Indonesia, National Science Museum Tokyo, Japan.

Heyne, K., 1987, Indonesian Useful Plants I, Forestry Research and Development, Jakarta. 
Hidayat, S., 2008, Structure, composition and status of medicinal plants in the forest area of Alas Purwo National Park, Jurnal Biologi 12(1), 9-13.

Khanduri, V.P., Sharma, C.M., Kumar, K.S., \& Ghildiyal, S.K., 2013, Annual variation in flowering phenology, pollination, mating system, and pollen yield in two natural populations of Schima wallichii (DC.) Korth., Sci. World J. 350157, 1-11.

Khanduri, V.P., 2014, Annual variation in floral phenology and pollen production in Lagerstroemia speciosa: an entomophilous tropical tree, J Sci. Tech. 36(4), 389-396.

Kumar, A.N., 2009, Exploring the "Bio-Cultural" Heritage in Conservation of 5 Rare, Endemic \& Threatened (RET) Tree Species of Western Ghats of Kerala, Final Report (2008-1009), MS Swaminathan Research Foundation Community Agrobiodiversity Centre, India.

Kurniawati, N., \& Martono, E., 2015, The role of flowering plants as a conservation media of arthropod natural enemies, Jurnal Perlindungan Tanaman Indonesia 19(2), 53-59.

Larcher, W., 1995, Physiological Plant Ecology, Springer Verlag, Berlin.

Lemmens, R.H.M.J., \& Bunyapraphatsara, N., 2003, Tacca palmate, Plant Resources of South East Asia No 12(3). Medicinal and Poisonous Plants 3, Prosea Foundation, Bogor.

Lestari, D.A., 2019, Evaluation of flowering and fruiting periods of selected Annonaceae species in Purwodadi Botanic Garden, AIP Conference Proceedings 2120, 030023, https:// doi.org/10.1063/1.5115627.

Lestari, D.A., \& Sofiah, S., 2015, Flowering and fruiting times on four species of Annona (Annonaceae) in Purwodadi Botanic Garden, JTLS 5(1), 45-52.

Micheloud, N.G., Castro, D.C., Buyatti, M.A., Gabriel, P.M., \& Gariglio, N.F., 2018, Factors affecting phenology of different Citrus varieties under the temperate climate conditions of Santa Fe, Argentina, Rev. Bras. Frutic. 40(1), 19.

Milla, R., Castro-Díez, P., Maestro-Martínez, M., \& Montserrat-Martí, G., 2006, Costs of reproduction as related to the timing of phenological phases in the dioecious shrub Pistacia lentiscus L. Plant Biol. 8(1), 103-111.

Mitchell, J.D., \& Daly, D.C., 2015, A revision of Spondias L. (Anacardiaceae) in the Neotropics, PhytoKeys 55, 1-92.
Mohandass, D., Campbell, M.J., Chen, X., \& Li, Q., 2018, Flowering and fruiting phenology of woody trees in the tropical-seasonal rainforest, Southwestern China, Current Sci. 114(11): 23132322.

Nanda, A., Suresh, H.S., \& Khrisnamurthy, Y.L., 2017, Phenology of tree species in a tropical evergreen forest of southern India, $J$ Global Ecol. Env. 6(1), 1-12.

Omondi, S.F., Odee, D.W., Ongamo, G.O., Kanya, J.I., \& Khasa, D.P., 2016, Synchrony in leafing, flowering, and fruiting phenology of Senegalia senegal within Lake Baringo Woodland, Kenya: Implication for conservation and tree improvement, IJFR 6904834, 11, http:// dx.doi.org/10.1155/2016/6904834.

Panchen, Z., 2016, Impact of climate change on flowering and fruiting times of Nunavut Arctic Plants, InfoNorth 69(4), 444-449.

Rianti, I.P., Santosa, Y., \&amp; Sunkar, A., 2009, Pola penggunaan ruang bertengger oleh beberapa jenis kelelawar penghuni gua di TNAP Jawa Timur [The pattern of use of perch space by several types of bats, cave dwellers in TNAP East Java], Indonesian Cave and Karst Journal 5(1), 36-47.

Sitompul, S.M., 2010, Radiation on Agroforestry System, http: / / old.worldagroforestry.org/sea/ Publications/files/lecturenote/LN0034-04/ LN0034-04-5.pdf., Accessed on 8 Oktober 2019.

Sulistyawati, E., Mashita, N., Setiawan, N.N., Choesin, D.N., \& Suryana, P., 2012, Flowering and fruiting phenology of tree species in Mount Papandayan Nature Reserve, West Java, Indonesia, TLSR 23(2), 81-95.

Tisnawati, V., Mala, Y.A., Utami, J., Yanuarefa, M.F., Pratiwi, L.E., Purwanto, Fahrurozi, R., Haryono, E., \& Wijayanti, A., 2012, Book of Alas Purwo National Park Research Information, Alas Purwo National Park, Banyuwangi.

Van Valkenburg, J.L.C.H., \& Bunyapraphatsara, N., 2002, Tetracera. In: van Valkenburg, J.L.C.H., \& Bunyapraphatsara, N. (eds), Plant Resources of South East Asia No 12(2). Medicinal and Poisonous Plants 2, Prosea Foundation, Bogor.

Widodo, W., 2016, Distribution and diversity of restricted-range bird species in the Alas Purwo National Park, Proceeding Biology Education Conference 13(1), 690-700. 